\title{
MENINGKATKAN PARIWISATA BALI MELALUI KEPASTIAN PENEGAKAN HUKUM ATAS PELANGGARAN KAWASAN TANPA ROKOK DALAM PERATURAN DAERAH PROPINSI BALI NOMOR 10 TAHUN 2011
}

\author{
Oleh: \\ I Gusti Agung Ngurah Iriandhika Prabhata'
}

\begin{abstract}
To obtain a good and healthy environment is a part of human rights, as stated in the constitution of the Republic of Indonesia and the global principles of human rights. Tourism in Indonesia held on the principle of upholding human rights, especially Bali which engaged in the tourism sector. In response to the Bali Provincial Government policies governing the protection of human rights to obtain a good and healthy environment, through the Bali Local Regulation No. 10 Year 2011 on No Smoking Area, but the policy can not work effectively due to the lack of certainty in terms of law enforcement that is set in the substance of the local regulation (vagueness of legal norms), as well as penalties for violations that have not been able to provide a deterrent effect.

This research uses normative legal research with the rationality that this study will examine the substance of the local regulation of Bali Province perceived No Smoking Area considered as vagueness of legal norm. The approach used to solve the problem is through the statute approach, analitical legal and conceptual approach, as well as the comparative approach to do a comparison of the rules banning smoking in Singapore and Queensland Australia.

The results showed that a good alternative No Smoking Area policy in Bali is reforming the Bali Local Regulation by inserting a clear formulation of the law enforcement authorities, as well as the formulation of assertive sanctions to provide a deterrent effect. Through law enforcement certainty No Smoking Area, it will be able to improve the quality of tourism in Bali, especially in terms of Cleanliness Personality and Comfort.
\end{abstract}

Keywords: (No Smoking Area), Human Rights, Rule of Law, Law Enforcement, Quality in Tourism.

Mahasiswa Magister Ilmu Hukum Universitas Udayana, Denpasar, Bali. Alamat Jalan Drupadi XIII/ NO. 10 E Denpasar, e-mail: prabhata1ir@hotmail. com 


\section{PENDAHULUAN}

\subsection{Latar Belakang}

Kesehatan merupakan bagian dari hak asasi manusia dan salah satu unsur kesejahteraan yang harus diwujudkan sesuai dengan cita-cita bangsa Indonesia. Sebagaimana yang tertuang di dalam ketentuan Pasal $28 \mathrm{H}$ ayat (1) UndangUndang Dasar Negara RI Tahun 1945 (selanjutnya disingkat UUD 1945).

Dalam perkembangannya, masih sering dijumpai pelanggaran-pelanggaran terhadap hak seseorang di bidang kesehatan. Salah satu hal yang aktual adalah gaya hidup masyarakat Indonesia dalam kegiatan merokok, dimana selain berdampak negatif bagi kesehatan perokok juga berdampak bagi kesehatan orang lain yang terpaksa harus terkena paparan asap rokok tersebut.

Menurut World Health Organization (WHO), kesadaran yang masih rendah dari masyarakat di seluruh dunia akan dampak negatif yang juga mematikan, akibat dari tembakau atau rokok. WHO mencatat adanya jumlah kematian yang sangat tinggi sekitar 11.000 orang tewas setiap harinya akibat penyakit dari tembakau. Bahkan tembakau setiap tahunnya menewaskan 4 juta orang di seluruh dunia dan ironisnya angka tersebut diperkirakan akan meningkat menjadi 10 juta dalam 25 tahun mendatang. ${ }^{2}$

URL:http://www.who.int/mediacentre/factsheets/ fs339/en/, Diakses Pada Tanggal 14 Pebruari 2014.
Terhadap pelanggaran di bidang kesehatan tersebut, selain pola prilaku masyarakat yang belum sadar terhadap arti pentingnya melakukan penghormatan terhadap hak-hak asasi manusia untuk memperoleh lingkungan yang bersih dan sehat. Hal ini tidak terlepas dari tingkat keefektifan hukum positif yang mengatur tentang kesehatan di Indonesia khususnya yang mengatur tentang rokok, baik dilihat dari segi substansi hukum (legal substance), struktur hukum (legal structure) maupun budaya hukum (legal culture).

Kegiatan pariwisata yang notabene adalah salah satu andalan bangsa Indonesia pun tidak bisa terlepas dari jaminan perlindungan hak asasi manusia baik yang melekat pada masyarakat Indonesia maupun pelaku pariwisata asing, karena dalam ketentuan Pasal 5 huruf b Undang-Undang No. 10 Tahun 2009 tentang Kepariwisataan (LN No. 11 Tahun 2009-TLN No. 4966), dinyatakan bahwa kepariwisataan yang diselenggarakan di Indonesia didasarkan atas prinsip menjunjung tinggi hak asasi manusia.

Bali merupakan pariwisata andalan bagi negara Indonesia, dengan meningkatnya kualitas pariwisata di Bali juga akan memberikan dampak positif bagi negara Indonesia, oleh sebab itu maka pada hakekatnya pengelolaan lingkungan hidup yang dilakukan oleh manusia adalah dengan melakukan upaya untuk meningkatkan kualitas hidup manusia itu sendiri terlebih dahulu, yang salah satunya dengan memperhatikan kesehatan sehingga 
nantinya dapat pula meningkatkan kualitas lingkungan hidup, dalam hal ini adalah destinasi pariwisata itu sendiri. ${ }^{3}$

Mengenai salah satu bentuk tindakan pemerintah khususnya dalam hal ini Pemerintah Provinsi Bali dalam menghadapi masalah tersebut adalah dengan membuat produk hukum berupa Peraturan Daerah Provinsi Bali No. 10 Tahun 2011 tentang Kawasan Tanpa Rokok (Lembaran Daerah Provinsi Bali Tahun 2011 Nomor 10 TLD No. 10, selanjutnya disingkat Perda Provinsi Bali tentang KTR). Perda Provinsi Bali tentang KTR dibentuk dengan tidak mengesampingkan peraturan perundangundangan diatasnya sesuai dengan hierarki peraturan perundang-undangan di Indonesia.

Ketentuan Perda Provinsi Bali tentang KTR secara jelas mengatur tentang kawasan mana saja yang terkena kebijakan sebagai KTR,namundemikiandidalamhalpenegakan hukumnya masih terdapat permasalahan akibat adanya kekaburan norma hukum dalam Perda tersebut. Di dalam ketentuan Pasal 13 ayat (1) dinyatakan bahwa "Setiap orang dilarang merokok di kawasan tanpa rokok". Sebagai sanksi terhadap pelanggaran Pasal 13 tersebut maka dalam ketentuan Pasal 18 ayat (1) dinyatakan bahwa "Setiap orang dan/atau badan yang melanggar ketentuan Pasal 12 dan Pasal 13 dipidana dengan pidana kurungan paling lama 3 (tiga) bulan atau denda paling banyak Rp.50.000,00

Moh. Soerjani, dkk. 2008, Lingkungan: Sumberdaya Alam Dan Kependudukan Dalam Pembangunan, Universitas Indonesia Press, Jakarta, h. 13. (lima puluh ribu rupiah)". Meski telah diatur mengenai sanksinya namun dalam Perda tersebut tidak secara jelas diatur mengenai lembaga dan proses penegakan hukum terkait pelanggaran di lapangan, di sisi lain dengan denda yang tergolong rendah tersebut dianggap tidak akan memberikan efek jera dan hanya akan membuka peluang bagi praktek-praktek Korupsi Kolusi dan Nepotisme (KKN). Oleh sebab itu proses penegakan hukum Perda Provinsi Bali Tentang KTR tersebut tidak dapat berjalan sebagaimana mestinya sebagai akibat pasalpasal dalam Perda mengenai penegakan hukumnya belum mengatur secara jelas, dengan kata lain terdapat kekaburan norma (vogue van normen).

Hukum pada dasarnya adalah tatanan objektif untuk mencapai kebajikan dan keadilan umum. ${ }^{4}$ Di samping itu proses penegakan hukum khususnya dalam hal pelanggaran terhadap kebijakan KTR ini masih belum mendapatkan tempat dalam ruang Kepastian, Keadilan, dan Kemanfaatan hukum, sebagaimana yang dikemukakan oleh Gustav Radbruch. ${ }^{5}$

\subsection{Rumusan Masalah}

Berdasarkan latar belakang tersebut diatas, adapun yang menjadi rumusan masalah adalah sebagai berikut:

Bernard L. Tanya. Dkk, 2010, Teori Hukum (Strategi tertib Manusia Lintas Ruang dan Generasi), Genta Publishing, Yogyakarta, h. 31.

Bernard Arief Sidharta, 2008, Meuwissen Tentang Pengembanan Hukum, Ilmu Hukum, Teori Hukum, dan Filsafat Hukum, Rafika Aditama, Bandung, h. 20 
1. Bagaimana menafsirkan mengenai ketentuan dan kewenangan penegakan hukum Kawasan Tanpa Rokok di Bali?

2. Bagaimanaketerkaitanantarakepastian penegakan hukum Kawasan Tanpa Rokok dengan upaya meningkatkan pariwisata Bali?

\subsection{Tujuan Penulisan}

1. Untuk mengetahui dan menganalisis bagaimana menafsirkan mengenai ketentuan kewenangan penegakan hukum Kawasan Tanpa Rokok di Bali.

2. Untuk mengetahui dan menganalisis bagaimana keterkaitan antara kepastian penegakan hukum Kawasan Tanpa Rokok dengan upaya meningkatkan pariwisata Bali.

\section{METODE PENELITIAN}

\subsection{Jenis Penelitian}

Jenis penelitian yang digunakan dalam penulisan ini adalah penelitian hukum normatif. Penelitian hukum normatif disebut juga sebagai penelitian hukum teoritis/ doktrinal, dimana fokus kajian dalam penelitian ini adalah dengan inventarisasi hukum positif, asas-asas dan doktrin hukum, penemuan hukum dalam perkara in concreto, sistematik hukum, taraf sinkronisasi hukum, perbandingan hukum, dan sejarah hukum. ${ }^{6}$ Penelitian hukum normatif ini berangkat dari masalah adanya kekaburan norma hukum dalam Peraturan Daerah Provinsi Bali No.

Bambang Sunggono, 2009, Metodologi Penelitian Hukum, Raja Grafindo Persada, Jakarta, h. 81-99.
10 Tahun 2011 Tentang Kawasan Tanpa Rokok, khususnya ketentuan yang mengatur mengenai penegakan hukum terhadap pelanggaran Perda tersebut.

\subsection{Jenis Pendekatan}

Dalam penelitian ini, peneliti menggunakan beberapa jenis pendekatan diantaranya:

1) Pendekatan Perundang-undangan (The Statute Approach). Dalam hal ini peneliti melakukan analisis terhadap peraturan-peraturan yang terkait dengan kebijakan tentang kawasan tanpa rokok, serta kebijakan di bidang kepariwisataan;

2) Pendekatan Analisis Konsep Hukum (Analitical and Conceptual Approach). Dalam hal ini peneliti melakukan analisis terhadap konsepkonsep hukum yang berhubungan dan menjadi dasar adanya kebijakan tentang kawasan tanpa rokok, serta hak asasi manusia untuk memperoleh lingkungan yang bersih dan sehat dalam perspektif kepariwisataan;

3) Pendekatan Perbandingan (Comparative Approach). Kaitannya dalam kekaburan norma, salah satu upaya peneliti untuk melakukan penemuan hukum adalah dengan melakukan perbandingan hukum. Dalam hal ini peneliti melakukan perbandingan hukum tentang aturan larangan merokok di Singapura melalui NEA (National Environtment Agency of Singapore) yang berupa Smoking Prohibition Law dan perbandingan 
hukum terhadap aturan larangan merokok di Queensland Australia yang berupa Queensland Tobacco Law. Dalam kaitan hal tersebut peneliti melakukan perbandingan terhadap kewenangan penegakan hukum yang diatur secara jelas di dalam aturan larangan merokok di negara lain dan instrumen sanksi yang digunakan sebagai salah satu upaya untuk memberikan efek jera bagi yang melanggar ketentun tersebut, dengan aturan kawasan tanpa rokok di Bali dalam Perda No. 10 Tahun 2011.

\section{HASIL PEMBAHASAN}

\subsection{Ketentuan dan Kewenangan Penegakan Hukum KTR}

Di dalam Perda Provinsi Bali tentang KTR terdapat kekaburan norma hukum dalam hal kewenangan penegakan hukum, serta pengaturan mengenai sanksi masih belum mampu memberikan efek jera. Terkait dengan kekaburan suatu norma hukum maka perlu adanya penafsiran/interpretasi hukum. Sementara Satjipto Rahardjo berpendapat bahwa hukum tidak dapat berjalan tanpa penafsiran, oleh karena hukum membutuhkan pemaknaan lebih lanjut agar menjadi lebih adil dan membumi. Membuat hukum adalah suatu hal dan menafsirkan hukum yang sudah dibuat merupakan keharusan berikutnya. ${ }^{7}$ Dalam memahami Perda Provinsi Bali

7 Eddy O.S. Hiariej, 2009, Asas Legalitas dan Penemuan Hukum Dalam Hukum Pidana, Erlangga, Jakarta, h. 65.

8 Asep Dedi Suwasta, 2012, Tafsir Hukum Positif Indonesia, Alia Publishing, Bandung, h. 9. tentang KTR, maka teknik interpretasi yang relevan digunakan dalam isu hukum terkait hal tersebut diatas meliputi:

1) Interpretasi Sistematis:

Penafsiran sistematis ini dilakukan dengan memandang bahwa tak satupun dari peraturan perundang-undangan dapat ditafsirkan seakan-akan berdiri sendiri, tetapi harus dipahami dalam kaitannya dengan jenis peraturan yang lainnya, atau dengan kata lain bahwa metode ini melihat hukum sebagai satu kesatuan yang utuh, tidak merupakan bagian yang berdiri sendiri tetapi merupakan bagian dari satu sistem. ${ }^{2}$

2) Interpretasi Gramatikal:

Metode penafsiran ini dilakukan dengan menuangkan isi peraturan perundang-undangan dalam bentuk bahasa tertulis. Untuk mengetahui makna ketentuan peraturan perundang-undangan yang belum jelas perlu ditafsiran dengan menguraikannya dengan bahasa yang baik.

\section{3) Interpretasi Perbandingan:}

Istilah comparative itu sendiri memberikan sifat kepada hukum yang dibandingkan. Maka dengan demikian, istilah perbandingan hukum lebih menitik beratkan kepada membandingan antara satu aturan hukum suatu negara tertentu dengan aturan hukum negara lain, dimana merupakan aturan hukum yang mengatur suatu hal yang sama.

4) Interpretasi Teleologis/Sosiologis:

Metode ini digunakan, apabila pemaknaan hukum ditafsirkan sesuai dengan tujuan dari pembuatan aturan 
hukum tersebut dan apa yang hendak dicapai dalam masyarakat. Dengan kata lain dapat juga dimaknai bahwa interpretasi ini terjadi apabila makna suatu undangundang ditetapkan berdasarkan tujuan kemasyarakatan, peraturan perundangundangan disesuaikan dengan hubungan dan situasi sosial yang baru. Ketentuan undangundang yang masih berlaku namun tidak sesuai lagi dengan realitas kemasyarakatan, jika diterapkan pada peristiwa hukum konkrit, maka undang-undang tersebut harus ditafsirkan ulang.

Mengenai Kewenangan Penegakan Hukum KTR, dalam penerapannya Perda Provisi Bali tentang KTR masih belum berjalan secara efektif dengan masih banyak terjadinya pelanggaran terhadap KTR dan peran serta masyarakat yang belum optimal. Selama ini dalam proses penegakan hukum dilaksanakan oleh Satpol PP Provinsi Bali yang memperoleh kewenangan berdasarkan undang-undang (atribusi). Mengacu pada pandangan Friedman bahwa penegakan hukum ditentukan oleh seberapa efektif aparat penegak hukum mampu menjalankan prosedur penegakan, dan jika dikaitkan dengan ketentuan penegakan hukum dalam Perda tersebut, maka substansi Perda Provinsi Bali tentang KTR belum memberikan kepastian dalam hal kewenangan penegakan hukumnya.

Terkait hal tersebut, di dalam ketentuan Pasal 148 Undang-Undang Nomor 32 Tahun 2004 jo Undang-Undang Nomor 12 Tahun 2008 Tentang Pemerintahan Daerah (LN No.59 Tahun 2008-TLN No.
4844), dinyatakan bahwa untuk membantu kepala daerah dalam menegakkan Perda dan penyelenggaraan ketertiban umum dan ketenteraman masyarakat dibentuk Satuan Polisi Pamong Praja (selanjutnya disebut Satpol PP). Dengan kata lain bahwa Satpol PP memiliki wewenang berdasarkan undangundang untuk melakukan penegakan atas Peraturan Daerah. Terhadap hal tersebut, tugas dan kewenangan Satpol PP berdasarkan atas Peraturan Pemerintah No. 6 Tahun 2010 Tentang Satuan Polisi Pamong Praja (LN No. 9 Tahun 2010-TLN No. 5094).

Mengacu pada ketentuan di dalam UU No. 12 Tahun 2008 dan PP No. 6 Tahun 2010 mengenai kewenangan, sudah diatur secara jelas bahwa kewenangan untuk menegakkan PerdaadalahdiberikankepadaSatpolPP,tidak terkecuali Perda Provinsi Bali tentang KTR, namun di dalam kenyataannya (das sein), Satpol PP tidak mampu melaksanakan tugas sebagaimana mestinya diakibatkan belum adanya pemahaman yang baik atas prosedur penegakan ketika terjadi pelanggaran KTR akibat tidak secara jelas diatur mengenai hal tersebut di dalam substansi Perda. Oleh sebab itu menjadi penting bagi Perda Provinsi Bali tentang KTR untuk merumuskan secara jelas mengenai kewenangan dan prosedur penegakan di dalam substansi hukum.

Dalam hal kawasan/tempat yang dapat dilakukan proses penegakan oleh Satpol PP Provinsi adalah tempat-tempat yang merupakan area yang ditetapkan sebagai Kawasan Tanpa Rokok berdasarkan Perda Provinsi Bali tentang KTR, sementara tempat-tempat sebagaimana yang ditetapkan 
sebagai KTR yang berada dalam wilayah hukum Kabupaten/Kota dapat ditegakkan oleh Satpol PP Kabupaten/Kota, namun bagi Kabupaten/Kota yang masih belum memiliki Perda tentang KTR atau masih dalam tahap sosialisasi maka penegakan dapat dilakukan oleh Satpol PP Provinsi dengan koordinasi kepada Satpol PP daerah masing-masing, namun kurangnya tenaga penyidik Satpol PP Provinsi berdampak bagi penegakan di lapangan.

Dengan kata lain, Satpol PP Provinsi masih bersifat fungsional, sehingga dalam proses penegakan hukumnya masih belum berjalan secara efektif, oleh sebab itu perlu adanya kepastian dalam pengaturan mengenai kewenangan penegakan hukum Perda Provinsi Bali tentang KTR.

UU No. 12 Tahun 2011 dalam ketentuan Pasal 15 ayat (2) telah memberikan legitimasi untuk dilakukannya perubahan atas rumusan sanksi bagi Perda Provinsi Bali tentang KTR, agar mampu memberikan efek jera. Dengan kata lain dalam pembentukan peraturan perundang-undangan harus benarbenar memerhatikan materi muatan yang tepat sesuai dengan hierarki peraturan perundang-undangan.

Menurut Hans Kelsen, hukum tidak lain merupakan norma utama yang mengandung sanksi di dalamnya. Law is the primary norm which stipulates the sanction. ${ }^{9}$ Sanksi-sanksi merupakan bagian penutup yang penting di dalam hukum, oleh karena kewajiban atau larangan yang termuat di

H.L.A. Hart, 1997, The Concept of Law, Oxford University Press, New York, h. 35. dalam suatu peraturan perundang-undangan tidak akan berguna jika aturan mengenai tingkah laku itu tidak dapat dipaksakan. ${ }^{10}$

\subsection{Kepastian Dalam Penegakan Hukum KTR Dikaitkan Dengan Peningkatan Pariwisata Bali}

Pulau Bali adalah bagian dari Kepulauan Sunda Kecil sepanjang 153 km dan selebar $112 \mathrm{~km}$ sekitar 3,2 km dari Pulau Jawa. Secara administratif Provinsi Bali terbagi atas 8 kabupaten, 1 kotamadya, 55 kecamatan, dan 701 desa/kelurahan.

Selain dari sektor pariwisata, penduduk Bali juga hidup dari pertanian dan perikanan, yang paling dikenal dunia dari pertanian di Bali ialah sistem Subak. Bali merupakan destinasi yang tidak asing lagi bagi sebagian besar wisatawan.

Mengenai upaya meningkatkan citra pariwisata dapat dilakukan salah satunya melalui branding. Dalam membentuk sebuah brand yang nantinya diharapkan dapat membawa perubahan kearah yang lebih baik bagi Bali, maka salah satu hal yang harus diperhatikan adalah mengenai personality. Perilaku masyarakat dan kepribadian yang baik dari masyarakat Bali merupakan hal yang penting karena sebuah brand hanyalah kata-kata ketika tidak didukung oleh budaya masyarakat yang baik.

Adapun personality yang dimaksud meliputi keramah tamahan masyarakat, jaminan keamanan, serta prilaku masyarakat yang menjaga kebersihan lingkungan

Philipus M. Hadjon.,et.al, 2011, Pengantar Hukum Administrasi Indonesia: Introduction to the Indonesian Administrative Law, Gadjah Mada University Press, Yogyakarta, h. 245. 
pariwisata (cleanliness). Di samping itu, mengkaji mengenai kepariwisataan yang berkelanjutan maka salah satu hal yang perlu menjadi perhatian adalah mengenai kebersihan lingkungan (environment purity), hal tersebut menjadi kewajiban semua stakeholders untuk melakukan tindakan to minimize the pollution of air, water and land and the generation of waste by tourism enterprises and visitor. ${ }^{11}$

Berbagai kebijakan telah dikeluarkan oleh Pemerintah Provinsi Bali terkait dengan kepariwisataan, karena melalui suatu kebijakan pula, sektor pariwisata akan berjalan secara berkelanjutan, sehingga manfaat dari pariwisata tidak hanya akan dirasakan oleh generasi saat ini melainkan juga generasi yang akan datang. Melalui kepastian penegakan hukum KTR, maka faktor meningkatnya kualitas suatu pariwisata akan terpenuhi, baik dari faktor Condition, Cleanliness maupun Physical and personal comfort. Oleh sebab itu, penting kiranya untuk menegakan aturan hukum yang berkaitan baik secara langsung maupun tidak langsung terhadap kepariwisataan di Bali.

Penelitian independen berulang kali membuktikan bahwa suatu negara atau wilayah dalam suatu negara tertentu yang menerapkan aturan mengenai larangan merokok, tidak memberikan efek negatif pada sektor ekonomi, bahkan mengalami peningkatan di sektor pariwisata dan

World Tourism Organization (UNWTO), 2011, Policy and Practice for Global Tourism, World Tourism Organization, Madrid Spain, h. 40-41. industri jasa lainnya. Studi yang dilakukan di California dan San Fransisco bahkan menunjukkan adanya peningkatan pendapatan di bidang pariwisata setelah menerapkan aturan kawasan tanpa rokok. ${ }^{12}$

Menguatkan hal tersebut American Medical Association melakukan penelitian dari beberapa kota besar di Amerika yang juga berjalan di sektor pariwisata seperti misalnya New York, Los Angeles, California, dll, mengalami peningkatan jumlah wisatawan dan pendapatan setelah menerapkan pengaturan tentang larangan merokok. ${ }^{13}$

Meningkatnya pendapatan di sektor pariwisata tersebut tidak lain akibat meningkatnya kualitas pariwisata itu sendiri, dengan kata lain penerapan aturan larangan merokok yang tegas akan memberikan dampak bagi kualitas pariwisata karena destinasi pariwisata tersebut mampu menjamin perlindungan HAM bagi masyarakat dalam hal ini wisatawan, serta memberikan perhatian juga terhadap kualitas lingkungan hidup.

Berdasarkan hal tersebut, maka dengan menerapkankebijakanKTRyangbaik, faktorfaktor yang mempengaruhi meningkatnya kualitas pariwisata di Bali akan terpenuhi, antara lain: faktor Physical and personal comfort, yaitu perlu menjaga kenyamanan bagi wisatawan yang berkunjung di destinasi

\footnotetext{
URL:http://www.cleanlungs.com/education/features/ tourism2.html, Diakses Pada Tanggal 11 Agustus 2014.

13 URL:http://www.lphi.org/LPHIadmin/uploads/ Tourism\%20Study-32064.pdf, Diakses Pada Tanggal 11 Agustus 2014.
} 
pariwisata, dengan melindungi wisatwan dari paparan asap rokok sehingga wisatawan akan merasa nyaman tanpa khawatir akan ancaman penyakit yang diakibatkan oleh asap rokok; dan faktor Attention to detail, memastikan bahwa setiap wisatawan memiliki hak yang sama untuk memperoleh standar tertentu dalam kegiatan pariwisata, baik bagi wisatawan sebagai perokok pasif dengan menerapkan larangan merokok di area tertentu, dan wisatawan sebagai perokok aktif untuk dibuatkan fasilitas ruangan khusus merokok; serta faktor Cleanliness, merupakan faktor terpenting untuk mengukur kualitas suatu pariwisata, yang dimaksud kebersihan dalam destinasi pariwisata adalah kebersihan lingkungan itu sendiri, tidak terkecuali kebersihan udara. Oleh sebab itu melalui kepastian penegakan hukum Perda Provinsi Bali tentang KTR, maka kebijakan KTR akan mampu diterapkan dengan baik, sehingga kualitas pariwisata Bali akan meningkat seiring berlakunya aturan KTR secara efektif di lapangan.

Adapun hakikat tujuan hukum adalah kepastian. Penegakan hukum adalah demi menjunjung tinggi kepastian hukum dan penegakan hukum tersebut adalah identik dengan penegakan keadilan. ${ }^{14}$ Oleh sebab itu dengan adanya kepastian hukum dalam hal penegakan Perda Provinsi Bali tentang KTR, maka Perda tersebut dapat memberikan kemanfaatan dan rasa adil bagi masyarakat maupun wisatawan.

Antonius Cahyadi, 2009, Sosiologi Hukum Dalam Perubahan, Buku Obor, Jakarta, h. 249.

\section{PENUTUP}

\subsection{Simpulan}

Berdasarkan uraian pembahasan tersebut diatas, maka dapat ditarik beberapa kesimpulan guna menjawab permasalahan yang dikemukakan dalam penelitian ini sebagai berikut:

1. Perda Provisi Bali tentang KTR di dalam penegakannya masih mengalami berbagai masalah akibat masih adanya kekaburan norma hukum, sehingga tidak adanya kepastian dalam hal kewenangan penegakan hukum. Oleh sebab itu perlu adanya penafsiran untuk menyelesaikan masalah tersebut, dengan menggunakan: interpretasi sistematis, yaitu melakukan penafsiran terhadap Perda Provinsi Bali tentang KTR dalam hubungannya sebagai satu sistem hukum dengan peraturan perundang-undangan lainnya baikyang berkedudukan secara vertikal maupun horizontal; interpretasi gramatikal/ bahasa, yaitu dengan menafsirkan substansi Perda Provinsi Bali tentang KTR khususnya dalam hal ini mengenai ketentuan penegakan hukum dan sanksi; interpretasi perbandingan, yaitu melakukan perbandingan Perda Provinsi Bali tentang KTR dengan pengaturan tentang larangan merokok di Singapura dan Queensland yang juga bergerak di sektor pariwisata. Kedua negara tersebut dapat menerapkan aturan larangan merokok dengan baik dikarenakan substansi dalam aturan larangan merokok secara 
jelas mengatur mengenai kewenangan penegakan hukum, sehingga mampu memberikan kepastian dalam penegakan, di samping itu juga rumusan instrumen sanksi pidana denda yang tegas mampu memberikan efek jera bagi yang melakukan pelanggaran terhadap aturan tersebut; dan yang terakhir dengan melakukan interpretasi sosiologis/ teleologis, yaitu tentang tujuan yang hendak dicapai suatu aturan hukum di dalam masyarakat, dalam hal ini tujuan Perda Provinsi Bali tentang KTR adalah untuk melindungi hak asasi masyarakat maupun wisatawan untuk memperoleh lingkungan yang baik dan sehat serta bebas dari asap rokok.

2. Adapun keterkaitan antara kepastian penegakan hukum KTR dengan meningkatkan pariwisata Bali, adalah dengan adanya jaminan kepastian dalam hal penegakan, maka proses penegakan hukum Perda tersebut dapat berjalan dengan baik. Melalui tegaknya dan berfungsinya norma hukum yang mengatur mengenai KTR tersebut maka akan menjamin HAM masyarakat maupun wisatawan untuk memperoleh lingkungan yang bersih dan sehat serta bebas dari asap rokok. Di samping itu dengan terpenuhinya faktor-faktor meningkatkan kualitas pariwisata seperti kebersihan dan kenyamanan dalam berwisata (cleanliness and personality comfort), maka pariwisata Bali akan memperoleh citra sebagai pariwisata yang berkualitas dan mampu menjamin hak-hak wisatawan dalam berwisata di mata dunia.

\subsection{Saran}

1. Perlu adanya perubahan substansi Peraturan Daerah Provinsi Bali No. 10 Tahun 2011 Tentang Kawasan Tanpa Rokok, dengan memuat kewenangan penegak hukum yang jelas sehingga tidak menimbulkan multi tafsir, dan membentuk satuan tugas khusus KTR, serta mengoptimalkan peran Dinas terkait dalam hal penegakan hukumnya. Di samping itu, perlu adanya perubahan atas rumusan instrumen sanksi pidana denda yang lebih besar agar dapat memberikan efek jera bagi pelanggar, sekaligus menjadi upaya untuk mencegah seseorang melakukan pelanggaran. Di sisi lain, dengan menerapkan prosedur pencegahan sebagaimana Singapura dengan pemasangan CCTV (closed circuit television) di berbagai tempat, maka akan mampu mengurangi ruang lingkup kesempatan seseorang untuk melakukan pelanggaran.

2. PariwisatadiIndonesiadiselenggarakan dengan prinsip menjunjung tinggi HAM, dan secara global kegiatan pariwisata saat ini menjadi bagian dari HAM. Oleh sebab itu sudah sepatutnya Pemerintah Provinsi Bali memberikan perhatian yang lebih terhadap sektor pariwisata yang notabene merupakan lokomotif ekonomi Bali. Melalui 
kebijakan-kebijakan agar pariwisata Bali dapat berlangsung secara berkelanjutan. Salah satunya dengan menerapkan kebijakan KTR dengan baik sehingga citra pariwisata Bali akan meningkat di mata dunia akibat terjaminnya HAM wisatawan untuk memperoleh lingkungan yang baik dan sehat

\section{DAFTAR PUSTAKA}

\section{Buku:}

Cahyadi, Antonius 2009, Sosiologi Hukum

Dalam Perubahan, Buku Obor, Jakarta.

Soerjani, Moh.,dkk. 2008, Lingkungan:

Sumberdaya Alam Dan Kependudukan

Dalam Pembangunan, Universitas Indonesia Press, Jakarta.

Tanya, Bernard L., Dkk, 2010, Teori Hukum

(Strategi tertib Manusia Lintas Ruang dan Generasi), Genta Publishing, Yogyakarta.

Sidharta, Bernard Arief 2008, Meuwissen Tentang Pengembanan Hukum, Ilmu Hukum, Teori Hukum, dan Filsafat Hukum, Rafika Aditama, Bandung.

Sunggono, Bambang, 2009, Metodologi

Penelitian Hukum, Raja Grafindo Persada, Jakarta.

Hiariej, Eddy O.S, 2009, Asas Legalitas dan Penemuan Hukum Dalam Hukum Pidana, Erlangga, Jakarta.

Suwasta, Asep Dedi, 2012, Tafsir Hukum Positif Indonesia, Alia Publishing, Bandung.
Hart, H.L.A, 1997, The Concept of Law, Oxford University Press, New York.

Hadjon, Philipus M.,et.al, 2011, Pengantar Hukum Administrasi Indonesia: Introduction to the Indonesian Administrative Law, Gadjah Mada University Press, Yogyakarta..

World Tourism Organization (UNWTO), 2011, Policy and Practice for Global Tourism, World Tourism Organization, Madrid Spain.

\section{Artikel Internet:}

URL:http://www.who.int/mediacentre/ factsheets/fs339/en/, Diakses Pada Tanggal 14 Pebruari 2014.

URL:http://www.cleanlungs.com/ education/features/tourism2.html, Diakses Pada Tanggal 11 Agustus 2014.

URL:http://www.lphi.org/LPHIadmin/ uploads/Tourism\%20Study-32064. $p d f$, Diakses Pada Tanggal 11 Agustus 2014.

\section{Peraturan Perundang-undangan:}

Undang-Undang Dasar Negara Republik Indonesia Tahun 1945.

Undang-Undang No. 39 Tahun 1999 Tentang Hak Asasi Manusia (Lembaran Negara Republik Indonesia Tahun 1999 Nomor 165 TLN No. 3886).

Undang-Undang Nomor 23 Tahun 2014 Tentang Pemerintahan Daerah (Lembaran Negara Republik Indonesia Nomor 244 TLN No. 5587). 
(UDAYANA MASTER LAW JOURNAL)

Undang-Undang No. 10 Tahun 2009

Tentang Kepariwisataan (Lembaran

Negara Republik Indonesia Tahun 2009 Nomor 11 TLN No. 4966).

Undang-Undang No. 12 Tahun 2011 Tentang

Pembentukkan Peraturan Perundang-

Undangan(Lembaran Negara Republik

Indonesia Tahun 2011 Nomor 82 TLN No. 5234).

Peraturan Pemerintah No. 6 Tahun 2010

Tentang Satuan Polisi Pamong Praja (Lembaran Negara Republik Indonesia Nomor 9 TLN No. 5094).

Peraturan Daerah Propinsi Bali No. 10 Tahun 2011 Tentang Kawasan Tanpa Rokok (Lembaran Daerah Propinsi Bali Tahun 2011 Nomor 10 TLD No. 10). 